\title{
Ameliorating Effect of $\beta$-Carotene on Haemato-Biochemical Parameters and Oxidative Stress Status during Gestational Stages in Goats
}

\author{
Anhar I. El-Hanafy ${ }^{1}$,Abdelkarim I.M. El-Sayed ${ }^{2}$, Mahmoud R.El-Mahdi ${ }^{2}$, Hassan A.M. Farghaly ${ }^{1}$ \\ andAkram A. El-Tarabany ${ }^{1}$ \\ 1. Department of Biological Applications, Radioisotopes Applications Division, Nuclear Research Center, \\ Atomic Energy Authority, Inshas, Cairo, Egypt, P.O.13759 \\ 2. Department of Animal Production, Faculty of Agriculture, Benha University, Benha, Egypt, P.O.13736. \\ Corresponding author:anhar_elhanafy@yahoo.com
}

\begin{abstract}
The possible effects of $\beta$-carotene orally supplementation upon gestational stages changes in serum concentrations across time for total protein (TP), albumin (ALB), globulin (GLB), total cholesterol (TC), triglyceride(TG) and alanine transaminase(AlT) and aspartate transaminase(AST), Haemoglobin (Hb), Red blood cells count (RBCs), packed cell volume (PCV) malondialdehyde(MDA),reduced glutathione(GSH), total antioxidant capacity(TAC) and progesterone (P4) were evaluated. Experiments were carried out from May to October and were constructed into two groups of gestational goats (20 does each) with 2-3 years (body weight $26 \pm 2 \mathrm{~kg}$ ) crossbred does $50 \%$ Zaraibi $x$ 50\% Baladi. The first group was considered as control (C) while the other one was $\beta$-carotene (BC) group in which $50 \mathrm{mg} \mathrm{BC}$ was oral supplemented/day/goat. Serum blood samples were collected in order to quantify progesterone concentrations (P4) through radioimmunoassay. TP, ALB, GLB, TC, and TG were analyzed spectrophotometrically. Oral supplementation with $\beta$-carotene significantly increased $(p \leq$ 0.05 ) the concentrations of TP, ALB,GLB, GSH,TAC and P4 with the associated significant decrease in TC, TG and MDA concentrations, compared with the control. Gestation stages showed significant differences ( $p$ $\leq 0.002$ and $\mathrm{p} \leq 0.05$ ) in all biochemical parameters, haematological, oxidative stress parameters and P4 level. However, a treatment $\times$ gestation stages interaction occurred between treatments for TP, ALT, AST, Hb, RBCs, PCV, MDA, GSH, TAC and P4 $(P<0.002$ and $\mathrm{p} \leq 0.05)$ favoring the $\beta$-carotene group.
\end{abstract}

Key words: Goats, gestation, $\beta$-carotene, haemato-biochemical parameters, oxidative stress parameters, Hormone

\section{Introduction}

Gestation is one of the important physiological stages in which nutritional needs are enhanced for supporting the growth and development of fetus. Nutrients including $\beta$-carotene are transmitted via maternal circulation and placental transfer to the fetus during pregnancy. During pregnancy, females are also more prone to oxidative stress caused by the imbalance between the prooxidant-antioxidant levels (Toescu et al., 2002). Thus, it is most likely that maternal $\beta$-carotene deficiency during pregnancy can lead to abnormal physiological function and poor health condition. Supplementation of either vitamin A or its precursor $\beta$-carotene promotes an ample range of biological processes such as cellular development, differentiation and morphogenesis through the action of retinoic acid (RA) (Amann et al., 2011). $\beta$-carotene is a potent scavenger of free radicals, especially singlet oxygen (Schweigert et al., 2003). Since RA interacts with nuclear receptors, it has the ability to modulate many gene products linked to reproductive performance (Schweigert et al., 2003; Amann et al., 2011).

In herbivorous ungulates, the largest $\beta$ carotene accumulation occurs in the liver with cattle and horses reflecting the highest $\beta$-carotene liver content, followed by goats, buffalo and sheep. Goats' $\beta$-carotene liver concentration is around $3.4 \mu \mathrm{g} / \mathrm{g}$ tissue (Darwish et al., 2016). Even though an optimal intake of $\beta$-carotene is hypothesized to affect ruminant reproduction, both negative (Folman et al., 1987) and positive effects have been reported (Kawashima et al., 2009).

Blood is an important and reliable medium for indicating the health status of individual animals. The blood parameters of animals can be greatly altered by numerous factors such as nutrition, disease, stress, parturition and climate. Therefore the hematological investigations served as basic information for animal health assistance. Previous studies have suggested that $\beta$-carotene supplementation can improve the immune function, reproductive and growth performance in goats (Dominic., 2016). Blood antioxidant status, hematological and biochemical parameters of goats can also be influenced by the $\beta$-carotene supplemented in diet (El-Demerdash et al., 2004). However, research work about the influence of dietary $\beta$ carotene on the antioxidant status, hormone profile and haemato-biochemical parameters of pregnant animals is rather limited. The objective of the present study was to gain insights regarding a possible relationship between $\beta$-carotene supplementation of crossbred goat does (50\% Zaraibi x $50 \%$ Baladi) and some of their blood biochemical, haematological and oxidative stress parameters as well as their hormonal levels, during gestation stages. 


\section{Material and methods}

\section{Animals and Feeding}

The experiment was carried out in the Experimental Farms Project (Goats Farm), Nuclear Research Center, Atomic Energy Authority, Inshas. The experimental goats were fed basal ration of concentrate feed mixture (CFM) according to the allowances of NRC (2007) of goats. The CFM composed of $37.4 \%$ wheat bran, $27 \%$ yellow corn, $12.5 \%$ soybean meal, $10.0 \%$ undecorticated cottonseed cake, $5 \%$ rice bran, $4 \%$ sugarcane molasses, 3\% limestone, $1 \%$ sodium chloride and 0.1 vitamin and minerals premix. Concentrate feed mixture (3.5\% of body weight)was offered once daily at $10 \mathrm{am}$. Barseem hay was offered ad libitum. Fresh drinking water was available at all time.

\section{Experimental Design}

Twenty pregnant female goats aged 2-3 years with average initial body weight $26 \pm 2 \mathrm{~kg}$ were randomly divided into two equal groups. Animals in the $1^{\text {st }}$ group were fed on basal ration without any additives (control), while the $2^{\text {nd }}$ group was fed basal ration and orally supplemented with $50 \mathrm{mg} \beta$-carotene /head /daily.

Ambient temperature, relative humidity and temperature humidity index

The ambient temperature and relative humidity were obtained daily from meteorological station of Atomic Energy Authority during the whole experimental period. The temperature humidity index (THI) was calculated during the whole pregnancy period from (May, 2014 to October, 2014) according to Maraiet al. (2000) as: $\mathrm{THI}=\mathrm{db}^{\circ} \mathrm{C}-[(0.31-$ $\left.0.31 \mathrm{RH}) \times\left(\mathrm{db}^{\circ} \mathrm{C}-14.4\right)\right]$, where, $\mathrm{THI}=$ temperature humidity index, $\mathrm{db}^{\circ} \mathrm{C}=$ dry bulb temperature in Celsius and $\mathrm{RH}=$ relative humidity $\%$. Since the averages of ambient temperature (AT), relative humidity (RH $\%)$ and temperature humidity index(THI)were $32.79^{\circ} \mathrm{C}, 76.16 \%$ and 31.43 , respectively.

\section{Haemato-biochemical parameter analysis}

Before the morning feeding two blood samples were collected biweekly from each animal via the jugular vein puncture. The first blood sample $(3 \mathrm{ml})$ was collected into an EDTA tube. In order to determine the hematological parameters, an automated analyzer (Autolyser AL 820, Swiss) was utilized to measure red blood cell (RBC) counts, hemoglobin $(\mathrm{Hb})$ concentration and the total leucocytes count (WBC). The second blood sample was handled to harvest serum samples and persevered at $\sim 20^{\circ} \mathrm{C}$. Serum total protein was determined via Biuret method (Armstrong and Carr, 1964). Serum cholesterol concentration was calibrated colorimetrically as described by Watson (1960).

\section{Assessment of oxidative stress and hormonal assay}

Reduced Glutathione (GSH) expressed as (umol/dl) were detected by High Performance Liquid Chromatography (HPLC) using the method of Jayatilleke and Shaw (1993). Total MDA (umol/dl)(Karatepe, 2004).Totalantioxidant capacity (TAC), and was expressed as $(\mathrm{mmol} / \mathrm{dl})($ El-Deeb and Younis, 2009). Hormonal analysis of progesterone (P4), were analyzed by direct radioimmunoassay technique (RIA).

\section{Statistical analysis}

Data were expressed as mean \pm SE. The data were analyzed statistically by GLM procedure of the SAS program (SAS, 1998). Duncan's Multiple Range test was used to detect the significant differences among means of the experimental groups (Duncan, 1955).

Using the following model: $Y i j k=\mu+T i+S j+(T S) i j+$ eijk Where: Yijk = the dependent variables estimated, $\mu=$ Overall mean, $\mathrm{Ti}=$ the effect of treatment $(1=$ control, 2 = beta carotene) $\mathrm{Sj}=$ the effect of gestation stages $(1=$ Early, $2=$ Mid and $3=$ Late $)$, TSij $=$ the effect of interaction between treatment and gestation stages, eijk = random error.

\section{Results}

\section{Biochemical parameters}

Biochemical parameters of pregnant does are presented in Tables 1and2. Total protein (8.730 \pm $0.075 \mathrm{~g} / \mathrm{dL})$, albumin $(5.237 \pm 0.065 \mathrm{~g} / \mathrm{dL})$ and Globulin $(3.500 \pm 0.052 \mathrm{~g} / \mathrm{dL})$, were significantly $(p \leq 0.05)$ increased by the $\beta$-carotene orally supplementation. While Total cholesterol (139.59 \pm $0.351 \mathrm{mg} / \mathrm{dL})$, Triglyceride $(122.67 \pm 0.301 \mathrm{mg} / \mathrm{dL})$ and the activities of ALT(39.50 $\pm 0.114 \mathrm{U} / \mathrm{L})$ and AST $(53.04 \pm 0.095)$ were significantly $(P<0.001)$ decreased by the $\beta$-carotene orally supplementation when compared with the control. Gestation stages showed a significant $(p \leq 0.05)$ effect and late gestation showed the highest mean concentration for TP, ALB, GLB, TC, TG concentrations and ALT and AST activities. Interestingly the interaction between $\beta$-carotene and gestation stages showed significant differences, except for ALB, GLB and TC the interaction showed no significant differences, such differences favored the $\beta$-carotene group. 
Table 1.Serum biochemical parameters of does, during gestation, as affected by treatment, gestation stages and their interactions.

\begin{tabular}{|c|c|c|c|}
\hline Item & TP (g/dL) & ALB (g/dL) & GLB (g/dL) \\
\hline \multicolumn{4}{|l|}{ Treatment $(\mathbf{T})$} \\
\hline Control & $6.16^{\mathrm{B}} \pm 0.074$ & $3.70^{\mathrm{B}} \pm 0.064$ & $2.46^{\mathrm{B}} \pm 0.051$ \\
\hline Beta carotene & $8.73^{\mathrm{A}} \pm 0.075$ & $5.24^{\mathrm{A}} \pm 0.065$ & $3.50^{\mathrm{A}} \pm 0.052$ \\
\hline Pvalues & 0.05 & 0.05 & 0.05 \\
\hline \multicolumn{4}{|c|}{ Gestation stages (S) } \\
\hline Early & $6.95^{\mathrm{C}} \pm 0.065$ & $4.17^{\mathrm{B}} \pm 0.055$ & $2.79^{\mathrm{B}} \pm 0.044$ \\
\hline Mid & $7.60^{\mathrm{B}} \pm 0.064$ & $4.54^{\mathrm{AB}} \pm 0.054$ & $3.05^{\mathrm{AB}} \pm 0.043$ \\
\hline Late & $7.80^{\mathrm{A}} \pm 0.066$ & $4.69^{\mathrm{A}} \pm 0.056$ & $3.11^{\mathrm{A}} \pm 0.045$ \\
\hline$P$ value & 0.05 & 0.05 & 0.05 \\
\hline \multicolumn{4}{|l|}{$(\mathbf{T} * \mathbf{S})$} \\
\hline \multicolumn{4}{|l|}{ Control } \\
\hline Early & $5.40^{\mathrm{b}} \pm 0.129$ & $3.24^{\mathrm{a}} \pm 0.111$ & $2.18^{\mathrm{b}} \pm 0.089$ \\
\hline Mid & $6.50^{\mathrm{a}} \pm 0.128$ & $3.90^{\mathrm{a}} \pm 0.110$ & $2.57^{\mathrm{a}} \pm 0.088$ \\
\hline Late & $6.58^{a} \pm 0.127$ & $3.95^{\mathrm{a}} \pm 0.112$ & $2.63^{\mathrm{a}} \pm 0.087$ \\
\hline \multicolumn{4}{|l|}{ Beta carotene } \\
\hline Early & $8.50^{\mathrm{a}} \pm 0.126$ & $5.10^{\mathrm{a}} \pm 0.113$ & $3.40^{\mathrm{b}} \pm 0.086$ \\
\hline Mid & $8.70^{\mathrm{b}} \pm 0.125$ & $5.18^{\mathrm{a}} \pm 0.114$ & $3.52^{\mathrm{a}} \pm 0.085$ \\
\hline Late & $9.01^{\mathrm{b}} \pm 0.124$ & $5.43^{\mathrm{a}} \pm 0.115$ & $3.58^{\mathrm{a}} \pm 0.084$ \\
\hline$P$ value & 0.05 & 0.157 & 0.175 \\
\hline
\end{tabular}

Means with different letters (A, B and C or $a, b, c, \ldots)$ in the same column within the same factor are significantly different at $(\mathrm{P}<0.05)$.

$\mathrm{TP}=$ Total protein; $\mathrm{ALB}=$ Albumin; GLB=Globulin.

Table 2. Serum biochemical parameters of doesduring gestation as affected by treatment, gestation stages and their interactions.

\begin{tabular}{|c|c|c|c|c|}
\hline Item & ALT (U/L) & AST (U/L) & TC (mg/dl) & TG (mg/dl) \\
\hline \multicolumn{5}{|l|}{ Treatment(T) } \\
\hline Control & $40.20^{\mathrm{A}} \pm 0.115$ & $57.99^{\mathrm{A}} \pm 0.096$ & $142.00^{\mathrm{A}} \pm 0.352$ & $125.33^{\mathrm{A}} \pm 0.300$ \\
\hline Beta carotene & $39.50^{\mathrm{B}} \pm 0.114$ & $53.04^{\mathrm{B}} \pm 0.095$ & $139.59^{\mathrm{B}} \pm 0.351$ & $122.67^{\mathrm{B}} \pm 0.301$ \\
\hline P values & 0.05 & 0.05 & 0.05 & 0.05 \\
\hline \multicolumn{5}{|c|}{ Gestation stages $(\mathrm{S})$} \\
\hline Early & $40.25^{\mathrm{B}} \pm 0.083$ & $52.00^{\mathrm{B}} \pm 0.100$ & $134.90^{C} \pm 0.305$ & $117.50^{\mathrm{C}} \pm 0.260$ \\
\hline Mid & $37.40^{\mathrm{C}} \pm 0.082$ & $50.35^{\mathrm{C}} \pm 0.101$ & $139.75^{\mathrm{B}} \pm 0.306$ & $118.50^{\mathrm{B}} \pm 0.261$ \\
\hline Late & $41.90^{\mathrm{A}} \pm 0.081$ & $61.36^{\mathrm{A}} \pm 0.081$ & $148.49^{\mathrm{A}} \pm 0.304$ & $131.50^{\mathrm{A}} \pm 0.262$ \\
\hline$P$ value & 0.05 & 0.05 & 0.05 & 0.05 \\
\hline \multicolumn{5}{|l|}{$(\mathbf{T} * \mathbf{S})$} \\
\hline \multicolumn{5}{|l|}{ Control } \\
\hline Early & $40.60^{\mathrm{a}} \pm 0.169$ & $55.40^{\mathrm{a}} \pm 0.199$ & $136.00^{c} \pm 0.604$ & $119.00^{\mathrm{a}} \pm 0.526$ \\
\hline Mid & $37.80^{\mathrm{b}} \pm 0.168$ & $51.40^{\mathrm{b}} \pm 0.195$ & $141.50^{b} \pm 0.603$ & $125.00^{\mathrm{a}} \pm 0.521$ \\
\hline Late & $42.20^{\mathrm{a}} \pm 0.167$ & $66.18^{a} \pm 0.198$ & $150.00^{\mathrm{a}} \pm 0.607$ & $133.00^{\mathrm{a}} \pm 0.522$ \\
\hline \multicolumn{5}{|l|}{ Beta carotene } \\
\hline Early & $39.90^{\mathrm{a}} \pm 0.166$ & $48.60^{a} \pm 0.197$ & $133.80^{c} \pm 0.607$ & $116.00^{\mathrm{b}} \pm 0.523$ \\
\hline Mid & $37.00^{\mathrm{b}} \pm 0.165$ & $49.30^{\mathrm{b}} \pm 0.196$ & $138.00^{b} \pm 0.606$ & $112.00^{\mathrm{a}} \pm 0.524$ \\
\hline Late & $41.60^{a} \pm 0.164$ & $56.49^{a} \pm 0.194$ & $146.98^{a} \pm 0.605$ & $130.00^{\mathrm{a}} \pm 0.525$ \\
\hline$P$ value & 0.05 & 0.05 & 0.1 & 0.007 \\
\hline
\end{tabular}

Means with different letters (A, B and C or $a, b, c, \ldots)$ in the same column within the same factor are significantly different at $(\mathrm{P}<0.05)$.

$\mathrm{ALT}=$ Alanine amino transferase; $\mathrm{AST}=$ Aspertate amino transferase; $\mathrm{TC}=$ Total Cholesterol; $\mathrm{TG}=\mathrm{Tri}$ glyceride .

\section{Haematological parameters}

Haematological parameters of pregnant does are presented in Table 3 . Hb $(9.367 \pm 0.063 \mathrm{~g} / \mathrm{dl})$, RBCs $\left(11.30 \pm 0.06410^{6} / \mu 1\right)$, PCV\%(27.10 $\left.\pm 0.068 \%\right)$, and WBCs $\quad\left(10.10 \pm 0.071 \quad 10^{3} / \mu 1\right) \quad$ were significantly $(p \leq 0.05)$ increased by the $\beta$-carotene orally supplementation, when compared with the control. Gestation stages showed a significant $(p \leq 0.05)$ effect and earlygestation showed the highest mean for $\mathrm{Hb}$ concentration, RBCs and WBCs counts. Interestingly the interaction between $\beta$-carotene and gestation stages showed significant differences, such differences favored the $\beta$-carotene group for $\mathrm{Hb}$ concentration, RBCs count and PCV\%. Except for WBCs count the interaction showed no significant differences. 


\section{Oxidative stress status parameters and hormonal} level

Oxidative stress status parameters of pregnant does are presented in Table4. MDA (1.09 $\pm 0.022 \mathrm{umol} / \mathrm{dL}), \mathrm{GSH} \quad(7.09 \pm 0.069 \mathrm{umol} / \mathrm{dL})$, TAC $\quad(7.70 \pm 0.074 \mathrm{mmol} / \mathrm{dl}), \quad$ and $\mathrm{P} 4$ $(24.893 \pm 0.074 \mathrm{ng} / \mathrm{mL})$ were significantly $(p \leq 0.05)$ increased by the $\beta$-carotene orally supplementation. when compared with the control. Gestation stages showed a significant $(p \leq 0.05)$ effect and mid gestation showed the highest mean for MDA, GSH, TAC and P4 concentrations while the lowest ones were in early gestation for MDA, GSH and P4 and late gestation for TAC. Interestingly the interaction between $\beta$-carotene and gestation stages showed significant differences, such differences favored the $\beta$-carotene group for MDA, GSH, TAC and P4 concentration.

\section{Discussion}

Current results support our working hypothesis in that $\beta$-carotene supplementation improved haematobiochemical, oxidative stress status and hormonal levels during gestation stages. $\beta$-carotene supplementation promotes the increasing, across gestation period, in blood metabolites specifically TP, ALB, GLB . The main increases were observed towards the late pregnancy. Despite our fragmentary knowledge regarding the mechanisms modulating the intermediate metabolism (Meza-Herrera and TenaSempere, 2012), results of our study suggest that such neurophysiologic scenario observed in the $\beta$-carotene supplemented gestational goats may potentially involve $\mathrm{BC}$ as an acting molecule involved in the intermediate metabolism, specially upon protein, carbohydrate, and lipid metabolism. However, TC and TG were decreased by supplementation of $\beta$-carotene this result is in agreement with results obtained by Bianca.,et al(1997) who demonstrated that $\beta$ carotene, and its precursor lycopene, suppress cellular cholesterol synthesis from acetate, but not from mevalonate in a concentration-dependent manner. This inhibition was concomitant with a stimulation of the LDL receptor in macrophages which could lead to enhanced of LDL from the plasma. Lavy et al (1993) and Levy et al (1995) previously have shown that carotenoids can bind to lipoproteins and to macrophages (Levy et al, 1996) and to affect their oxidative state.

Table 3. Haematological parameters of does during gestation as affected by treatment, gestation stages and their interactions.

\begin{tabular}{|c|c|c|c|c|}
\hline Item & Hb (g/dl) & RBCs $\left(10^{6} / \mu \mathrm{l}\right)$ & PCV (\%) & WBCs $\left(10^{3} / \mu \mathrm{l}\right)$ \\
\hline \multicolumn{5}{|l|}{ Treatments(T) } \\
\hline Control & $8.729^{\mathrm{B}} \pm 0.064$ & $10.91^{\mathrm{B}} \pm 0.053$ & $26.47^{\mathrm{B}} \pm 0.069$ & $9.70^{\mathrm{A}} \pm 0.074$ \\
\hline Beta carotene & $9.367^{\mathrm{A}} \pm 0.063$ & $11.30^{\mathrm{A}} \pm 0.052$ & $27.10^{\mathrm{A}} \pm 0.068$ & $10.10^{\mathrm{A}} \pm 0.071$ \\
\hline P values & 0.05 & 0.05 & 0.05 & 0.05 \\
\hline \multicolumn{5}{|c|}{ Gestation stages (S) } \\
\hline Early & $9.35^{\mathrm{A}} \pm 0.055$ & $11.68^{\mathrm{A}} \pm 0.059$ & $26.75^{\mathrm{B}} \pm 0.060$ & $10.23^{\mathrm{A}} \pm 0.064$ \\
\hline Mid & $8.90^{\mathrm{A}} \pm 0.054$ & $10.48^{\mathrm{C}} \pm 0.058$ & $25.62^{\mathrm{C}} \pm 0.061$ & $9.55^{\mathrm{B}} \pm 0.063$ \\
\hline Late & $8.89^{\mathrm{A}} \pm 0.053$ & $11.15^{\mathrm{B}} \pm 0.057$ & $27.99^{\mathrm{A}} \pm 0.062$ & $9.96^{\mathrm{AB}} \pm 0.062$ \\
\hline$P$ value & 0.002 & 0.05 & 0.05 & 0.05 \\
\hline \multicolumn{5}{|l|}{$(\mathbf{T} * \mathbf{S})$} \\
\hline \multicolumn{5}{|l|}{ Control } \\
\hline Early & $8.90^{\mathrm{b}} \pm 0.106$ & $10.56^{\mathrm{b}} \pm 0.114$ & $26.50^{\mathrm{b}} \pm 0.119$ & $9.90^{\mathrm{a}} \pm 0.129$ \\
\hline Mid & $8.41^{\mathrm{c}} \pm 0.107$ & $10.16^{\mathrm{b}} \pm 0.113$ & $25.03^{\mathrm{c}} \pm 0.118$ & $9.30^{\mathrm{a}} \pm 0.128$ \\
\hline Late & $8.88^{\mathrm{a}} \pm 0.108$ & $11.00^{\mathrm{a}} \pm 0.112$ & $27.89^{\mathrm{a}} \pm 0.117$ & $9.90^{\mathrm{a}} \pm 0.127$ \\
\hline \multicolumn{5}{|l|}{ Beta carotene } \\
\hline Early & $9.80^{\mathrm{a}} \pm 0.101$ & $11.80^{\mathrm{a}} \pm 0.117$ & $27.00^{\mathrm{a}} \pm 0.116$ & $10.50^{\mathrm{a}} \pm 0.126$ \\
\hline Mid & $9.40^{\mathrm{a}} \pm 0.102$ & $10.80^{\mathrm{b}} \pm 0.116$ & $26.20^{\mathrm{b}} \pm 0.115$ & $9.80^{\mathrm{b}} \pm 0.125$ \\
\hline Late & $8.90^{\mathrm{a}} \pm 0.103$ & $11.30^{\mathrm{a}} \pm 0.115$ & $28.10^{\mathrm{a}} \pm 0.114$ & $10.01^{\mathrm{b}} \pm 0.124$ \\
\hline$P$ value & 0.05 & 0.05 & 0.05 & 0.02 \\
\hline
\end{tabular}

Means with different letters $(\mathrm{A}, \mathrm{B}$ and $\mathrm{C}$ or $\mathrm{a}, \mathrm{b}, \mathrm{c}, \ldots)$ in the same column within the same factor are significantly different at $(\mathrm{P}<0.05)$.

$\mathrm{Hb}=$ Haemoglobin; $\mathrm{RBCs}=$ Red blood cells count; $\mathrm{PCV}=$ Packed cell volume; WBCs= White blood cells count. 
Table 4.Antioxidant status parameters in blood and p4 of does during gestation, as affected by treatment, gestation stages and their interactions.

\begin{tabular}{|c|c|c|c|c|}
\hline Item & MDA(umol/dl) & GSH (umol /dl) & TAC (mmol /dl) & P4(ng/ml) \\
\hline \multicolumn{5}{|l|}{ Treatment(T) } \\
\hline Control & $1.35^{\mathrm{A}} \pm 0.023$ & $6.42^{\mathrm{B}} \pm 0.072$ & $6.60^{\mathrm{D}} \pm 0.073$ & $23.17^{\mathrm{C}} \pm 0.075$ \\
\hline Beta carotene & $1.09^{\mathrm{BC}} \pm 0.022$ & $7.09^{\mathrm{A}} \pm 0.069$ & $7.70^{\mathrm{B}} \pm 0.074$ & $24.90^{\mathrm{B}} \pm 0.074$ \\
\hline P values & 0.05 & 0.05 & 0.001 & 0.001 \\
\hline \multicolumn{5}{|c|}{ Gestation stages (S) } \\
\hline Early & $0.91^{\mathrm{C}} \pm 0.026$ & $5.09^{C} \pm 0.062$ & $7.25^{\mathrm{B}} \pm 0.063$ & $19.26^{\mathrm{C}} \pm 0.065$ \\
\hline Mid & $1.65^{\mathrm{A}} \pm 0.024$ & $9.22^{\mathrm{A}} \pm 0.061$ & $7.65^{\mathrm{A}} \pm 0.064$ & $26.80^{\mathrm{A}} \pm 0.064$ \\
\hline Late & $1.09^{\mathrm{B}} \pm 0.027$ & $5.75^{\mathrm{B}} \pm 0.063$ & $6.55^{\mathrm{C}} \pm 0.065$ & $24.98^{\mathrm{B}} \pm 0.063$ \\
\hline$P$ value & 0.05 & 0.05 & 0.05 & 0.05 \\
\hline \multicolumn{5}{|l|}{$(\mathbf{T} * \mathbf{S})$} \\
\hline \multicolumn{5}{|l|}{ Control } \\
\hline Early & $1.00^{\mathrm{a}} \pm 0.040$ & $4.98^{c} \pm 0.120$ & $6.50^{\mathrm{d}} \pm 0.127$ & $16.50^{\mathrm{d}} \pm 0.130$ \\
\hline Mid & $1.90^{\mathrm{a}} \pm 0.042$ & $8.78^{\mathrm{d}} \pm 0.121$ & $7.00^{d} \pm 0.126$ & $27.00^{c} \pm 0.131$ \\
\hline Late & $1.14^{\mathrm{a}} \pm 0.041$ & $5.50^{\mathrm{d}} \pm 0.122$ & $6.30^{\mathrm{d}} \pm 0.125$ & $26.00^{\mathrm{b}} \pm 0.132$ \\
\hline \multicolumn{5}{|l|}{ Beta carotene } \\
\hline Early & $0.82^{\mathrm{b}} \pm 0.043$ & $5.20^{b} \pm 0.123$ & $8.00^{\mathrm{b}} \pm 0.124$ & $20.00^{\mathrm{b}} \pm 0.133$ \\
\hline Mid & $1.40^{\mathrm{c}} \pm 0.044$ & $9.65^{\mathrm{a}} \pm 0.124$ & $8.30^{\mathrm{b}} \pm 0.123$ & $28.00^{\mathrm{b}} \pm 0.134$ \\
\hline Late & $1.04^{\mathrm{ab}} \pm 0.045$ & $5.99^{\mathrm{a}} \pm 0.131$ & $6.80^{\mathrm{b}} \pm 0.122$ & $26.68^{\mathrm{a}} \pm 0.135$ \\
\hline$P$ value & 0.05 & 0.002 & 0.05 & 0.05 \\
\hline
\end{tabular}

Shokrzadehet al. (2012) and Draeger et al. (2014) stated thatvitamin A supplementation was significantly decreased serum levels of the liver function biomarkers, AST and ALT. This may possibly explained by the antioxidant activity of vitamin A which can protect the liver from free radicals generated by metabolic reactions.

$\beta$-carotene orally supplementation enhanced blood haematological values and these findings were similar to those of Bendich (1991), AMAR et al. 2000 and El-Demerdashet al. (2004) whom illustrated that carotenoids have been implicated in enhancing the immune response such as proliferation, induction of specific effector cells as well as the secretion of cytokines. $\beta$-carotene levels up to $200 \mathrm{mg} \mathrm{kg}^{-1}$ diet enhanced some immune parameters like serum complement and total plasma immunoglobulin in the experimental rainbow trout. Moreover, immunoenhancement of $\beta$-carotene involves the quenching of free radicals or the lowering of lipid peroxide levels and alterations in membrane fluidity, which account on increasing the levels of RBCs, Hb, and PCV upon its supplementation in diet. These results may partly due to theantioxidant activity of vitamin A. It has been regarded that improving antioxidant status enhanced immune function of animals (Grimble, 2001). Bendich and Shapiro (1986) reported that supplementation rat with the vitamin $A$ or $\beta$-carotene protected its immune responses to certain environmental sources of free radicals. Vitamin A can function as natural antioxidants to remove harmful free radicals produced through normal cellular activity and from environmental stressors, thereby maintaining the structural integrity of immune cells (Chew, 1996).

Malondialhyde is a good indicator of lipid peroxidation which can generally be used as a biomarker for radical induced damage and endogenous lipid peroxidation (Wang et al., 2008). In the present study, MDA concentration in the serum was reduced by inclusion of $\beta$-carotene supplementation. This may be due to what stated by Tsuchihashiet al. (1995) that beta-carotene and other carotenoids are widely regarded as biological antioxidants. Carotenoids can inhibit the propagation of radical initiated lipid peroxidation. Modulation of lipid peroxidation by alpha-tocopherol or betacarotene may be an important mechanism for reducing oxidative stress. And what had demonstrated by Salem (2015) that the supplementation oflycopene, $\beta$ carotene or their mixture in rats resulted in a significant reduction of liver MDA, and asignificant elevation of liver and blood glutathione (GSH), in comparison with the levels of high fat dietgroup. Thesupplementation oflycopene, $\beta$-carotene or their mixture resulted in a significant reduction of liver MDA, and asignificant elevation of liver and blood glutathione (GSH), in comparison with the levels of high fat dietgroup.

The present results elucidated that $\beta$-carotene eliviated progesterone $(\mathrm{P} 4)$ concentration during gestation periods. A number of studies have reported either positive effect or no effect of supplemental $\beta$ carotene on concentration of reproductive hormones in various animal species. However, limited studies have been conducted in goats, therefore studies from other species were discussed. Concerning P4 
concentrations, contradicting results have been reported. It was found that the $\mathrm{P} 4$ concentration was increased through supplemental $\beta$-carotene in cattle (Greenberg et al., 1986) and goats (ArellanoRodriguez et al., 2009).

\section{Conclusion}

The current study reported that $\beta$-carotene supplementation $(50 \mathrm{mg} /$ day/doe $)$ generates serum biochemical, haematological, oxidative stress parameters as well as progesterone concentrations across gestation stages in does goats.

\section{References}

Amar, E. C.;Kiron,V; Satoh, SH.; Okamoto, N. and Watanabe, T.( 2000).Effects of dietary bcarotene on the immune response of rainbow trout Oncorhynchusmykiss. Fisheries Science 2000; 66: 1068-1075

Amann, P.M.;Eichmuler, S.B.; Schmidt, J. andBazhin, A.V.( 2011). Regulation of gene expression by retinoids. Curr. Med. Chem. 18: 1405-1412.

Arellano-Rodriguez, G.; Meza-Herrera, C.A.; Rodriguez-Martinez, R.;Dionisio Tapia, R.; Hallford, D.M.;Mellado, M.; GonzalezBulnes, A. (2009). Short-term intake of $\beta$ carotene-supplemented diets enhances ovarian function and progesterone synthesis in goats. J. Anim. Physiol. Anim. Nutr. 93: 710-715.

Armstrong, W.D.; Carr, C.W.(1964). Physiological Chemistry Laboratory Directions, third ed. Burges Publishing Co., Minneapolis, MN.

Bendich, A. (1991). $\beta$-carotene and the immune response. Proceedings of the Nutrition Society 50:263-274

Bendich, A. and Shapiro, S. S. (1986). Effect of bcarotene and canthaxanthin on the immune response of the rat. Journal of Nutrition 116:2254-2262.

Bianca, F.; Avishay, E.; and Michael, A. (1997).Hypocholesterolemic effect of lycopene and $\beta$-Carotene is related to suppression of cholesterol synthesis and augmentation of LDL receptor activity in macrophages. Biochemical and Biophysical RESEARCH COMMUNICATIONS 233: 658-662, NO. RC976520

Chew,B.P. (1996).Importance of antioxidant vitamins in immunity and health in animals. Animal Feed Science and Technology. 59,(13), 103-114

Darwish, W.S.; Ikenaka, Y.;Morsdy, A.E.;Eldesorky, K.I.; Nakayama andMizukawa, N. (2016). $\beta$-Carotene and retinol contents in the meat of herbivorous ungulates with special reference to their public health importance. J. Vet. Med. Sci. 78: 351-354
Dominic,L.M 2016. Effect of $\beta$ carotene supplementation on oestroussynchronisation and milk production of Saanen goats. MSC, Fac. Nat and Agric.Sci. Dep.Anim. Wild. Sci. Univ .Pretoria.

Draeger. C. L ;Naves. A; Marques,N; Ana Beatriz Baptistella. A ; Carnauba. R. A; Paschoal, V and Nicastro, H. (2014). Controversies of antioxidant vitamins supplementation in exercise: ergogenic or ergolytic effects in humans? https://doi.org/10.1186/1550-2783-11-4.

Duncan, D.B. (1955). Multiple range and multiple Ftest. Biometrics, 11:1-42.

El-Deeb, W.M .and Younis, E.E. (2009). Clinical and biochemical studies on Theileriaannulata in Egyptian buffaloes (Bubalusbubalis)with particular orientation to oxidative stress and ketosis relationship. Vet .Parasitol, 164: 301305.

El-Demerdash, M.; Yousef, M. I ;Kedwany. F. S. and Baghdadi, H. H.(2004). Role of $\alpha$ Tocopherol and $\beta$-Carotene in ameliorating the fenvalerate-induced changes in oxidative stress, hemato-biochemical parameters, and semen quality of male rats. JOURNAL OF ENVIRONMENTAL SCIENCE AND HEALTH Part B-Pesticides, Food Contaminants, and Agricultural Wastes. 39 (3): 443-459.

Folman, Y.; Ascarelli, I.; Kraus, D.;Barash, H., (1987). Adverse effect of beta- carotene in diet on fertility of dairy cows. Dairy Sci. 70: 357366.

Greenberg, L. G.; Bristol, F.; Murphy, B. D.andLaarveld, B. (1986). Beta-carotene does not influence fertility in beef heifers. Theriogenology. 26:491-508.

Grimble. R. F. (2001). Nutritional modulation of immune function. Symposium on Evidencebased nutrition. Proceedings of the Nutrition Society, 60: 389397.

Jayatilleke, E. and Shaw, S.(1993). A highperformance liquid chromatographic assay for reduced and oxidized glutathione in biological samples. Journal of Analytical Biochemistry. Vol 214.( 2): 452-457.

Karatepe (2004). Simultaneous determination of ascorbic acid and free malondialdehyde in human serum by HPLC-UV. LCGC NORTH AMERICA 22( 4):362-365 .

Kawashima, C.; Kida, K.; Schweigert, F.J.;, Miyamoto, A.(2009). Relationship between plasma betacarotene concentrations during the peripartum period and ovulation in the first follicular wave postpartum in dairy cows. Anim. Reprod. Sci. 111: 105-111.

Lavy, A.; Ben Amotz, A. and Aviram, M. (1993) Preferential inhibition of LDL oxidation by the all-trans isomer of beta-carotene in comparison 
with 9-cis beta-carotene. J. Clin. Chem .Clin. Biochem. 31: 83-90.

Levy, Y.; Ben-Amotz, A. and Aviram, M. (1995). Effect of dietary supplementation of different $\beta$ carotene isomers on lipoprotein oxidative modification. J. Nutr. Environ. Med. 5, 13-22.

Levy, Y.; Kaplan, M.; Ben Amotz, A. and Aviram, M. (1996). The effect of dietary supplementation of $\beta$-carotene on human monocyte-macrophagemediated oxidation of low density lipoprotein. Israel J. Med. Sci. 32(6), 473-478.

Marai, I.F.M.; Bahgat, L.B.;Shalaby, T.H. and Abdel-Hafez, M.A. (2000). Fattening performance, some behavioural traits and physiological reactions of male lambs fed concentrates mixture alone with or without natural clay, under hot summer of Egypt. Ann. Arid Zone, 39 (4): 449-460.

Meza-Herrera C.A. andTena-Sempere M. (2012): Interface between nutrition and reproduction: the very basis of production. In: Astiz S., GonzalezBulnes A. (eds): Animal Reproduction in Livestock. In: Encyclopedia of Life Support Systems. Eolss Publishers, Oxford, UK.

NRC. (2007). Nutrient Requirements of Small Ruminants: Sheep, Goats, Cervids, and New World Camelids. Natl. Acad. Press, Washington, DC.

Salem A.S. 2015. Effect of two carotenoids (Lycopene and $\beta$-Carotene) supplementation on hyperlipidemia and lipid peroxidation in experimental albino rats. Journal of High Institute of Public Health 2015;45(1):1-7..
SAS, 1998. Statistical analysis system user's guide, Release 6.0 ed. 4 th edition, SAS Institute Inc. Cary, NC, USA.

Schweigert, F.J.; Steihage, N.B.;Raila, J.;Seimann, A.;Peet, D. andBuscher, U. (2003). Concentrations of carotenoids, retinol and $\alpha$ tocopherol in plasma and follicular fluid of woman undergoing IVF. Hum. Reprod. 18, 1259-1264.

Shokrzadeh. M ;Shobi. S;Attar. H;Shayegan. S;Sadat .S;Payam. H and Ghorbani, F. (2012). Effect of vitamins $A, E$ and $C$ on liver enzyme activity in rats exposed to organophosphate pesticide Diazinon. Pakistan Journal of BiologicalSciences Volume 15 (19): 936-941.

Toescu . V; Nuttall. S. L;Martin. U;Kendall. M. J. andDunne.F. (2002). Oxidative stress and normal pregnancy. Clin Endocrinol (Oxf). 57(5):609-13.

Tsuchihashi .H; Kigoshi. M; Iwatsuki. M; Niki. E. (1995). Action of $\beta$-Carotene as an antioxidant against lipid peroxidation. Archives of Biochemistry and Biophysics. 323, (1):137-147.

Wang, Y.Z.; C.L. Xu; Z.H. An; J.X. Liu and Feng, J. (2008). Effect of dietary bovine lactoferrin on performance and antioxidant status of piglets. Anim. Feed Sci. Technol., 140: 326-336. DOI10.1016/j.anifeedsci.2007.02.006

Watson, D. (1960). A simple method for the determination of serum cholesterol. Clin. Chem. Acta 5: 637-638.

$$
\begin{aligned}
& \text { التأثير المحسن للبيتا كاروتين على المؤثرات الاموية البيوكيميائية ومؤثرات الإجهاد التأكسدى خلال فترات الحمل فى الماعز } \\
& \text { انهار إبراهيم الحنفي } 1 \text { - عبد الكريم إبراهيم محمد السيد² - محمود رياض المهاي2 - حسن أحمد مصطفى فرغلي } 1 \text { - أكرم عبد الستار } \\
& \text { الطرباني } \\
& \text { 1. قسم النطبيقات البيولوجية - شعبة تطبيقات النظائر المشعة - مركز البحث النورية - هيئة الطاقة الذرية }
\end{aligned}
$$

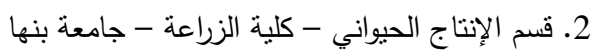

بهدف هذا البحث دراسة التأثيرات المحتملةلإضافة البيتاكاروتين عن طريق الفم على التغيرات الدموية والبيوكيميائية ومؤشرات الإجهاد التأكسى بالإضافة إلى التغيرات فى مستوى هرمون البروجستيرون خلال فترات الحمل المختلفة .اجريت الدراساتخلال الفترة من شهر مايو وحتى شهر أكتوبر

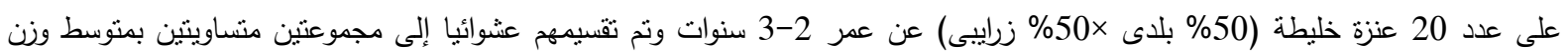

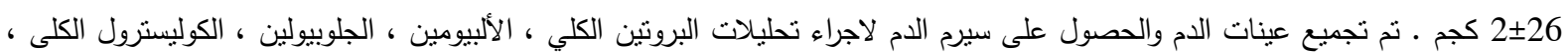
الدهون الثلاثية ، بالإضافة إلى هرمون البروجسنيرونالذي تم تقديرة بطريقة المناعه الإشعاعية - خلال ،

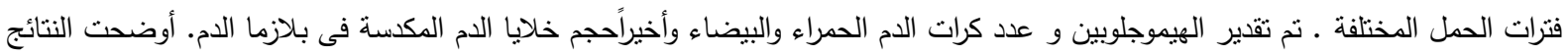
أن استخدام البيتاكاروتين أدى الى ذيادة معنوية فى كل من البروتين الكلى ، الألبيومين ، الجلوبيولين ،الجلوتاثيثون المختزل والسعة التأكسدية الكلية

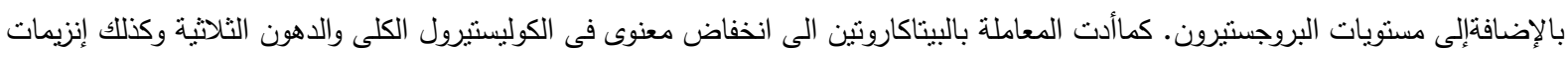
الكبد بالإضافة إلى التأثير المشترك بين المعاملة وفترات الحمل على البروتين الكلى و إنزيمات الكبد والهيموجلوبين وعدد كرات الدم الحمراء وحجم

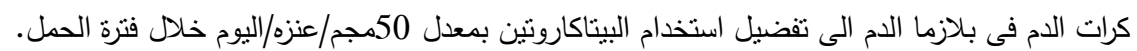

